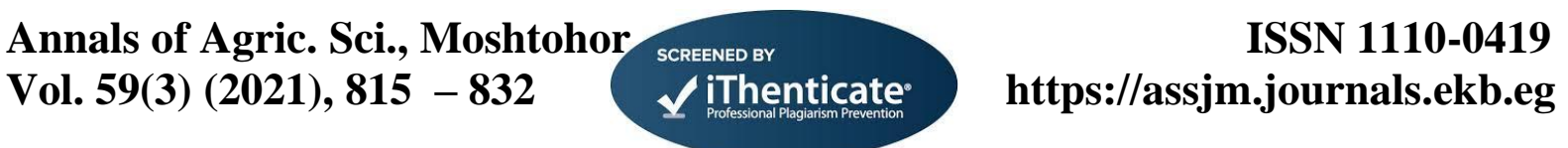

\title{
Biological and Molecular Characteristics of Potato Virus $X$ Naturally Infected Potato Plants
}

\author{
Ghada A. Hassan ${ }^{1}$, Nawal A .Eisaa ${ }^{1}$, Fawzy R.N ${ }^{1}$.El DougdougK.A ${ }^{2}$ and Eman O. Hassan ${ }^{1}$ \\ 1-Dept of Plant Pathology, Fac. of Agric.(Moshtoher), Univ. of Benha .Egypt. \\ 2- Virology Lab., Dept., of Microbiology Fac. of Agric. Univ. of Ain Shams Egypt.
}

*Corresponding author: eman.ali@fagr.bu.edu.eg

\begin{abstract}
:
Potato viruses were been identified in several countries around the world included Egypt. Potato virus $X$ (PVX), is one of the common viruses infecting . potato crops . In the current study PVX isolated from naturally mixed viruses and identified based on biological characters ; serologically and molecularly. The incidence of , PVY , PVX , PLRV, AMV, TYLCV were found single and mixing infection with 33.3, 37.1 , $12.38,12.38,5.12 \%$ frequency respectively out of 105 natural infected potato plants cv. Sponta. PVX was detected by distinct symptoms (severe mosaic, yellow blotch ) and DAS-ELISA. It was isolated on Chenopodium.amaranticolor and Datora. stramonium L .It had wide host range, transmitted mechanically by syringe injection and Grafted tuber,. The virus particles rod with length wide (475) nm and (12) nm . The virus stability was TIP expected at $80^{\circ} \mathrm{C}$ for $10 \mathrm{~min}$. DEP expected at $10^{-8}$ and LIVexpected at 7 days. It was formed amorphous and crystal inclusion bodies in epidermal cells. PVX have antigenicity character that serological precipitation reactionwith DAS-ELISA . PVX infectivity revealed that $90 \%$, disease severity $85 \%$ and high concentration in infected potato plants. The partial nucleotide sequence of $\mathrm{CP}$ gene was about $433 \mathrm{bp}$. The genetic distance with other recommended PVX strains registered in GenBank with 10 bar . The similarity values were recorded 100\% with GU384726 1, 97.92 \% with Accession no.MK587495, MF662526 , KR605392, KR605379, KR605360 and 98.30\% similarity with strain no.KJ631111..The predict numbers 144 amino acids were starting with Tyrosine. The genetic distance with other recommended PVX strains registered in GenBank with 0.20 bar It was recorded in gene bank with accession number MW 650651
\end{abstract}

Key words: PVX ; Hosts range ; ELISA ; TEM ; Stability ,RT PCR ; Coat protein gene; gene bank,

\section{Introduction}

Potato virus $X$ (PVX), is one of the common viruses infecting potato crops (Nyalugwe et al., 2012 and Fayziev \& Vakhabov, 2019). PVX belong to genus Potexvirus and family Alphaflexiviridae, is a rod-shaped virus containing single stranded RNA capped, polyadenylated, and contains five open reading frames (ORFs) (Huisman et al., 1988). ORF 1 encodes a $166 \mathrm{KDa}$ protein which functions as a replicase. ORFs 2, 3 and 4 encode proteins of 25,12 and $8 \mathrm{KDa}$, respectively, and are known as the triple gene block. These gene products are thought to be involved in cell-to-cell movement of the virus. The fifth ORF encodes the coat protein, which is $25 \mathrm{KDa}$ in size (Hefferon et al., 1997). Potato crop as a fourth one. after wheat and mays in the world . Potato tubers crop is most important food in worldwide included Egypt . Egypt is among countries of the world top potato exporter (Crissman, et al., 1991 ; Hegazy, 2009; ElDougdoug et al., 2014, Faostat, 2018 and Noha and Nglaa,2020). PVX has a fairly narrow host range mostly limited to the Solanaceae family and causes mild mosaic symptoms in potato plants (Bercks, 1970). PVX is the most widespread of potato viruses and often completely infects certain commercial stocks, causing yield reductions estimated to be more than $15 \%$ (Torrance et al., 1986). PVX may be latent, with foliage symptoms or effect on plant vigor, detectable only when closely compared to PVX-free stocks. PVX was first recognized in UK (Smith, 1931), it has since been shown to be very common and widespread, occurring wherever potatoes are grown. Therefore, to find a rapid, accurate and sensitive method for detection of the virus is very essential (Soliman et al., 2000). RTPCR determines the size of the cDNA, as well as defining regions that would be most suitable for diagnosis of viruses under testing (Puurand et al., 1994). The production of subgenomic RNAs (sgRNAs) is one of the strategies by which internally located open reading frames (ORFs) of multicistronic RNA virus may be expressed and regulated during replication (Yun et al., 2000). The present study Isolated PVX. from mixing infection in natural infected potato plants and identified based on characterized biological ,serological and molecular.

\section{Materials and Methods}

This study was conducted during the period from 2018-2020 for isolation and identification Potato mosaic virus (PVX) from naturally mixed infection potato plants cv. Sponta .

Detection of Potato mosaic virus (PVX) : One hundred and five collected from naturally infected potato plants cv. Sponta showed different virus like symptoms (fig.1) cultivated at autumn season 2018/2020 in farms , Qalubia governorate.The 
collected infected potato plants were investigated for incidence of some common viruses infected potato in Egypt. Based on distanced symptoms and polyclonal antibody kits for PVY, PVX , PLRV, AMV , and TYLCV. The serological Kits were obtained from Agric. Research Center (ARC) provided by (LOEWE Biochemica GmbH Germany) by double antibodies sandwich enzyme linked immunosurbant assay (DAS-ELISA) according to (Clark and Adams, 1977).

Isolation of Potato mosaic virus :

PVX was isolated from infected potato leaves whish gave positive result with serologically polyclonal antibody kits of PVX. The virus inoculum was prepared in $0.1 \mathrm{M}$ phosphate buffer $\mathrm{pH}$ $7.4(1 \mathrm{ml} / 1 \mathrm{~g})$ and grinded in 600 mesh carborandum in sterilized mortar and pestle. The expressed juice was filtrated through two layers of cheesecloth. Indicator plants Chenopodium amaranticolor and Datora stramonium L., were grown into clay soil in pots under a greenhouse conditions. The healthy leaves of at 21 days were mechanical inoculated by cotton swab dipped in virus inoculum. Five repeatedly growing plants for virus isolate were inoculated per trail .

Propagation of Potato mosaic virus (PVX) :

The virus inoculum was prepared from PVX infectious of $D$ stramonium sap and mechanically inoculated on Nicotiana tobacum cv.samson. The inoculated plants were kept under insect-proof cages at greenhouse conditions at $26 \pm 1{ }^{\circ} \mathrm{C}$ and $16 \mathrm{~h}$ daylight to 21 days. The external symptoms were observed and confirmed by DAS-ELISA. The infected plants used as a virus source.

\section{Identification of isolated Potato mosaic virus :}

Host range : Eighteen of different plant species belonging to four families shown in table (4) were mechanically inoculated with the virus inoculum. Five seedlings of each host were inoculated and observed daily for symptoms development. Two healthy seedlings of the each host were left without inoculation as a control. Inoculated plants were kept under observation in insect-proof greenhouse at $26 \pm 1^{\circ} \mathrm{C}$ for three to five weeks after inoculation symptoms appearance and confirmed by DASELISA.

\section{Mode of transmission:}

Sap mechanical transmission was done on host range by mechanical inoculation with virus inoculum dipped in sap inoculums. As well as inoculum sap were mechanically injected in meddle vein and axillary buds on stem of host plants by syringe according to Allam et al. (1994) . The inoculated plants as well as uninoculated ones were kept in insect-proof cages under greenhouse conditions, and observed daily for the developed external symptoms. The results were confirmed by DAS-ELISA .
Potato tuber transmission was done on healthy potato tubers cv. Spount were grafted by infected bud eyes from PVX infected potato tubers (Noha and Nagllaa,2020) and covered by paraffin wax according to Nyalugwe,,et al.,(2012). The inoculated tubers were planted in pots with sterilized clay soil and kept in insect-proof cages under greenhouse conditions. The developed external symptoms were observed daily on plants growth. The results were confirmed by DAS-ELISA .

\section{Stability of isolated virus:}

The virus stability (TIP), (DEP) and( LIV) were determined in infectious crude sap from $N$. tabaccum cv.Samson leaves. The treated infectious sap was indexed on Ch. amaranticolor $\mathrm{L}$ at 21 days as indicator plants and kept under a greenhouse conditions. The results were calculated as a local chlorotic lesions according to (Walkey, 1985) as the following:

Thermal Inactivation Point (TIP): The infectious sap was dispersed in $2 \mathrm{ml}$ Eppendrof tubes and heated at certain temperatures $\left(50^{\circ} \mathrm{C}\right.$, up to $90^{\circ} \mathrm{C}$ intervals $5^{0} \mathrm{C}$ in water bath for $10 \mathrm{~min}$. The treated tubes were cooled by dipping in cold water. Each treated and untreated infectious sap were inoculated on three-leaves of three Ch. amaranticolor L., plants. Dilution End Point (DEP) :The infectious sap was serially diluted in ten fold dilutions starting from $10^{-}$ 1 to $10^{-9}$. Each dilution of infectious sap and undiluted one were inoculated on three-leaves of three Ch. amaranticolor L ., plants .

Longevity in vitro (LIV) : The infectious sap was distributed in $2 \mathrm{ml}$ Eppendrof tubes and kept at room temperature $\left(25^{\circ} \mathrm{C}\right)$ for 1 to 10 days. Every day, one tube used for inoculate three-leaves of three healthy Ch. amaranticolor L., plants

Inclusion bodies : The cytoplasmic crystalline and amorphous viral inclusions were detected in epidermal strips of systemically PVX N. tabaccum cv.Samson leaves. The strips were removed using a forceps, then mounted in distilled water then staining with $5 \%$ Triton-XI00 for 5 minutes, then immerse the strips directly in mercuric bromo phenol blue stain for 15 minutes, then transfer the strips to $0.5 \%$ acetic acid for 15 minutes according to (Jordan and Baker, 1955) method, then washed in distilled water for 10 minutes and mounted on glass slide. The presence of amorphous inclusions was investigated in the epidermal strips by using light microscope at magnification of 400X.

Transmission Electron Microscope : Of $N$. tabaccum cv.samson leaves were extracted in $0.1 \mathrm{M}$ phosphate buffer ${ }_{\mathrm{PH}} 7.0(1: 2 \mathrm{~W}$ : V), The infectious sap was clarified using n-butanol and chloroform(1:1 $\mathrm{V}: \mathrm{V}$ ) at room temperature, The clarification sap was centrifuged at differential low $6000 \mathrm{rpm}$ at $4^{\circ} \mathrm{C}$ for $15 \mathrm{~min}$. and high $30000 \mathrm{rpm}$ at $4^{\circ} \mathrm{C}$ for $15 \mathrm{~min}$. Small drops of purified virus were placed on a carbon 
coated grids for one min. then dried with edge of small filter paper. the grids were stained using $2 \%$ uranyl acetate, $\mathrm{PH} 7.0$ for one min. to dry according to (Noordam, 1973) the grids were examined using electron microscope (JEOL-JEM-1010) inThe Regional Center for Mycology Al-Azhar Univeresity.

Disease severity : The disease severity for each potato cultivar was determined using the following rating:

Scale: $0=$ no symptoms; $2=$ vein clearing; $4=$ mosaic; $6=$ start necrosis; $8=50 \%$ necrosis $+50 \%$ mosaic; $10=$ apical necrosis. Disease severity (DS) values were calculated using the following formula according to (Yang et al., 1996).

DS $=\frac{?(\text { disease grade } \times \text { No. of plants in each grade })}{(\text { total No } . \text { of plants } \times \text { highest disease grade })}$
$\times 100$

Reverse transcription- polymerase chain reaction (RT-PCR)

Extraction of total RNA $50 \mathrm{mg}$ infected $N$. tabaccum cv.samson leaves according to the instruction manual of High Pure RNA tissue kit (Version 1, 2000) from Roche diagnostics $\mathrm{GmbH}$, Germany. The eluted RNA was stored at $-80{ }^{\circ} \mathrm{C}$ for later analysis. Purified RNA was confirmed by UV spectrophotometer 260 and $280 \mathrm{~nm}$ and separated on $1.5 \%$ Agarose electrophoresis.

Primer synthesis : Two oligonucleotide primers were synthesized to generate a cDNA and amplify the PVX CP gene . sense primer $\left(5^{\prime}\right.$ gettcaggactgttcacc $\left.3^{\prime}\right)$ and antisense primer (5'gcaacgaatgacgacctc3'), (Joojin ,et.al. . 2015 ). . The oligonucleotide primers were synthesized in Thenno Hybaid GmbH, Germany.

cDNA synthesis : cDNA was synthesized as according to (Joojin ,et.al. . 2015 ). For each sample, twenty $\mu \mathrm{l}$ of reaction solution $1 \mu \mathrm{g}$ of total RNA , $3 \mu \mathrm{l}$ of antisense primer (5'gcaacgaatgacgacctc 3 '), PCR reaction solution (4 $\mu 1$ of $5 X$ first strand cDNA buffer, $5 \mu$ l of $0.3 \mathrm{M} \mathrm{2- \beta}$ mercaptoethanol, $2.5 \mu \mathrm{l}$ of $10 \mathrm{mM}$ each deoxynucleotide triphosphate (dNTPs), $1 \mu \mathrm{l}$ of RNasin (40 units/ $\mu \mathrm{l}$ ), $2 \mu \mathrm{l}$ of $0.1 \mathrm{M}$ dithiothreitol (DTT), and $1 \mu \mathrm{l}$ (10.000 units/ $\mu \mathrm{l})$ of Moloney Murine Leukamia Virus reverse transcriptase (MMLV-RT), (Promega, Co) and deionized water to a volume of $20 \mu \mathrm{l}$ were mixed with annealing reaction mixture, and incubated for 1 hour at $42^{\circ} \mathrm{C}$.

Amplification of cDNA : Amplification was perfomed in thin walled PCR tubes. Each tube containing the following reaction mixture, $5 \mu \mathrm{l}$ of 10xPCR buffer, $3 \mu \mathrm{l}$ of $25 \mathrm{mM} \mathrm{MgCl}_{2}, 1 \mu \mathrm{l}$ of 10 $\mathrm{mM}$ dNTPs, $5 \mu \mathrm{l}$ of $10 \mathrm{pmol}$ each Sense primer $\left(5^{\prime}\right.$ gettcaggactgttcacc $\left.3^{\prime}\right)$ and antisense primer (5'gcaacgaatgacgacctc3') for PVX-CP, 2.5 units of Taq DNA polymerase, and sterile water to a volume of $50 \mu \mathrm{l}$, in a programmable thermocycler. Five $\mu \mathrm{l}$ of the cDNA mixture was added to the PCR reaction and amplified with the following cycling parameters. The RT-PCR conditions were $30 \mathrm{~min}$ at $50^{\circ} \mathrm{C}, 2 \mathrm{~min}$ at $94^{\circ} \mathrm{C}, 30$ cycles of $1 \mathrm{~min}$ at $94^{\circ} \mathrm{C}, 1 \mathrm{~min}$ at $45^{\circ} \mathrm{C}, 1$ min at $72^{\circ} \mathrm{C}$ and 10 at $72^{\circ} \mathrm{C}$ The amplified product was resolved by electrophoresis in $1 \%$ agarose gel.

Electrophoresis analysis, aliquots $10 \mu \mathrm{l}$ of RT-PCR amplified DNA product were mixed with $2 \mu \mathrm{l}$ of gel loading buffer $(20 \mathrm{mg}$ bromophenol blue, $20 \mathrm{mg}$ xylene cyanol, $20 \mathrm{ml}$ orange $\mathrm{G}, 20 \mathrm{~g}$ sucrose, water to $100 \mathrm{ml}$ ), and separated on a $1 \%$ agarose gel in $1 \mathrm{X}$ TBE buffer ( $1 \mathrm{X}=89 \mathrm{mM}$ Tris, $89 \mathrm{mM}$ borate, and 2 mM EDTA, pH 8.3). DNA was stained with ethidium bromide added to the gel at a concentration of $0.5 \mu \mathrm{g} / \mathrm{ml}$. DNA was visualized on a UV transilluminator (wavelength $=254 \mathrm{~nm}$ ) and photographed using Gel Documentation System (GELDOC 2000, BioRad, USA) pGEM DNA leader (Promega) was used to determine the size of RTPCR amplified cDNA products.

Bio-informatic analysis of Sequence : The RTPCR product was direct sequenced by the dideoxy chain termination method, using a 377 DNA sequencer (ABI, USA). Nucleotide sequence was compared with those available in GenBank (https://www.ncbi.nlm.nih.gov), and the amino acid sequence was estimated through the translation tool from Expasy Software (https://www.expasy.org/tools/). Multiple sequence alignments and sequence relationship were produced using CLUSTAL W (Thompson et al., 1997), and calculation of percentage of identity was performed by analysis on (http:// bioinformatics.org/ sms/ ident_sim.html).

\section{Results}

Virological characteristic.

Potato mosaic virus (PVX) isolated from naturally infected potato plants cv. Sponta(fig.1) was identified based on biologically ; serologically and molecularly.

1- Incidence of potato viruses

The incidence of some potato viruses PVY, PVX , PLRV, AMV ,TYLCV in potato plants cv. Sponta were determined based on distinct viral symptoms (crinkling, lead narrow, mild mosaic, necrosis , severe mosaic venial necrosis, yellow ) and using specific polyclonal antibody by DAS-ELISA .(table 1). The virus frequency was PVY, PVX , PLRV, AMV , TYLCV with 33.3, 37.1 , 12.38, $12.38,5.12 \%$ respectively out of 105 natural infected potato plants (fig.1 \&Table.2). 


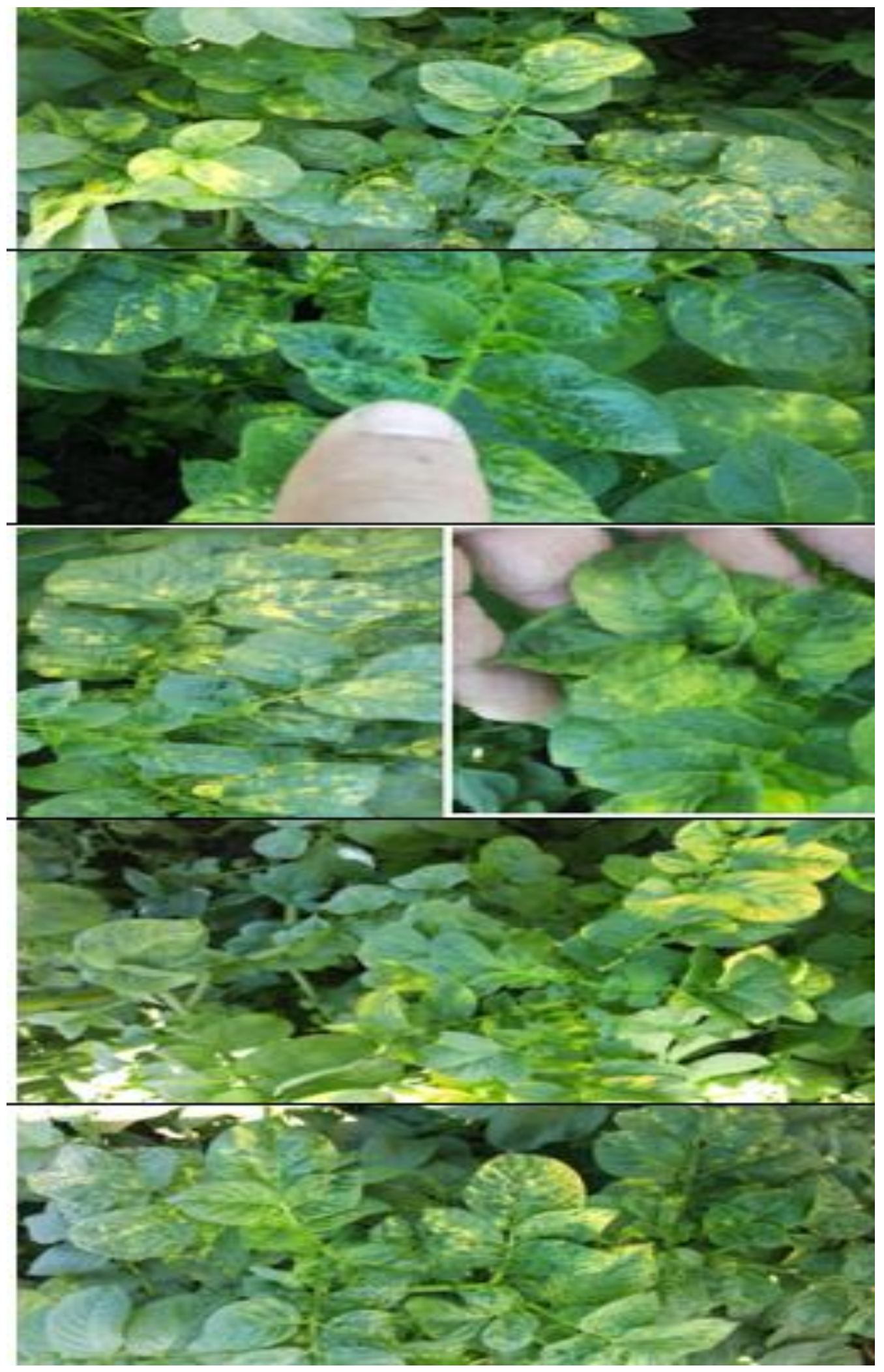

Fig. (1): Natural infected potato plants in field exhibit viral symptoms. 
Table 1. Symptoms and serological detection of potato viruses in naturally infected potato plants cv . sponta showing virus symptoms virus diseases in field using DAS-ELISA.

\begin{tabular}{|c|c|c|c|c|c|c|c|c|c|c|c|}
\hline Symptoms & \multirow{2}{*}{$\begin{array}{c}\begin{array}{c}\text { Symptoms } \\
\text { like }\end{array} \\
\text { mild, mosaic }\end{array}$} & \multicolumn{2}{|c|}{$\overline{P V X}$} & \multicolumn{2}{|c|}{ AMV } & \multicolumn{2}{|c|}{ PVY } & \multicolumn{2}{|c|}{$\begin{array}{c}\text { Geminivirus } \\
\text { (TYLCV) }\end{array}$} & \multicolumn{2}{|c|}{ PLRV } \\
\hline & & 0.432 & + & 0.498 & + & 0.422 & - & 0.285 & - & 0.285 & - \\
\hline & $\begin{array}{c}\text { severe } \\
\text { mosaic, } \\
\text { crinkle, leaf } \\
\text { narrow }\end{array}$ & 0.453 & + & 0.484 & + & 0.328 & - & 0.836 & + & 0.326 & - \\
\hline & $\begin{array}{c}\text { mottling, } \\
\text { curl }\end{array}$ & 0.532 & + & 0.392 & - & 0.345 & - & 0.596 & - & 0.321 & - \\
\hline & $\begin{array}{c}\text { Vein yellow } \\
\text { curl } \\
\text { cub shape } \\
\text { leaf narow }\end{array}$ & 0.238 & - & 0.251 & - & 0.366 & - & 0.693 & ++ & 0.304 & - \\
\hline & $\begin{array}{l}\text { Yellow } \\
\text { mosaic, } \\
\text { leaf narow } \\
\text { rugosity }\end{array}$ & 0.356 & - & 0.533 & + & 0.361 & - & 1.030 & + & 0.196 & - \\
\hline & $\begin{array}{l}\text { Yellow } \\
\text { mosaic }\end{array}$ & 0.576 & + & 0.467 & - & 0.406 & - & 0.742 & + & 0.243 & - \\
\hline & $\begin{array}{l}\text { Severe } \\
\text { mosaic }\end{array}$ & 0.512 & - & 0.657 & + & 0,236 & - & 0.224 & - & 0.476 & + \\
\hline & $\begin{array}{l}\text { Yellow } \\
\text { botchs }\end{array}$ & 0.375 & - & 0.427 & - & 0.285 & - & 0.387 & - & 0.229 & - \\
\hline
\end{tabular}

Positive control $=0.482$

Negative control $=0.236$ 
Table 2. Incidence and Frequency of potato viruses in natural infected potato plants in field exhibit viral symptoms

\begin{tabular}{|c|c|c|c|c|c|}
\hline \multirow[t]{2}{*}{ Virus incidence } & \multicolumn{2}{|c|}{$\begin{array}{c}\text { No of Natural infected potato } \\
\text { plants }(n=105)\end{array}$} & \multicolumn{3}{|c|}{ Virus Frequency } \\
\hline & Number & $\%$ & virus & No & $\%$ \\
\hline Healthy & 33 & 31.4 & - & - & - \\
\hline Potato virus (PVY) & 13 & 12.4 & PVY & 39 & 33.3 \\
\hline Potato virus (PVX) & 17 & 16.2 & PVX & 37 & 37.1 \\
\hline Potato leaf roll virus (PLRV) & 2 & 1.9 & PLRV & 11 & 12.3 \\
\hline Alfa Alfa mosaic virus (AMV) & 6 & 5.7 & AMV & 11 & 12.3 \\
\hline Gemenivirus (TYLCV) & 2 & 1.9 & TYLCV & 6 & 5.12 \\
\hline $\mathrm{PVY}+\mathrm{PVX}$ & 12 & 12.3 & & & \\
\hline PVY + PLRV & 4 & 3.8 & & & \\
\hline PVY + AMV & 2 & 1.9 & & & \\
\hline PVY+ TYLCV & 2 & 0 & & & \\
\hline PVX+ PLRV & 4 & 2.9 & & & \\
\hline PVX+ AMV & 4 & 2.9 & & & \\
\hline PVX+ TYLCV & 0 & 0 & & & \\
\hline PLRV+ AMV & 0 & 0 & & & \\
\hline PLRV+ TYLCV & 0 & 0 & & & \\
\hline AMV + TYLCV & 2 & 0 & & & \\
\hline PVY + PVX + PLRV & 2 & 2.8 & & & \\
\hline $\mathrm{PVY}+\mathrm{AMV}+\mathrm{TYLCV}$ & 0 & 0 & & & \\
\hline PVX + PLRV + TYLCV & 0 & 1.9 & & & \\
\hline PLRV + AMV + TYLCV & 0 & 0 & & & \\
\hline $\begin{array}{c}\mathrm{PVY}+\mathrm{PVX}+\mathrm{PLRV}+\mathrm{AMV}+ \\
\text { TYLCV }\end{array}$ & 0 & 0 & & & \\
\hline
\end{tabular}

\section{2-Virus isolation}

According to distinct symptoms (severe mosaic, yellow blotch ) on potato plants and DAS-ELISA these potato plants were chosen to be virus isolation . on Ch.amaranticolor. After 9 to 13 days post inoculation showed local lesions . The homologous local lesions (small round, chlorotic lesions with yellow halo) were extracted in $0.1 \mathrm{M}$ phosphate buffer PH (7.0) and reinoculated on Datura stramonium $\mathrm{L}$. It was exhibited systemic infection as (vein clearing, , crinkling, deformation and blotch mosaic) on leaves.(fig. 2) which confirmed by DASELISA

\section{Identification of PVX}

The isolate virus was identified as being PVX based on host range, mode of transmission, virus stability, inclusion bodies, virus morphology, serological reaction and coat protein gene.

Host range : Plant host species (table,3) belonging to four families were showed different reactions at the 4-5 leaves-old stage with isolated virus . Their reaction dived into three types of reaction (table, $3 \&$ fig. 1).. First reaction systemic symptoms with, D. stramonium L. , Nicotiana glutinosa L., N.rustica, N. Samson L, Pepper , Capsicum annum, Petunia hyprida, Solanum nigrum L., S. esculantum L.cv. Castle rock , Petunia hyprida, and Phaseulus vulgaris L. (Giza 3). Secand reaction local symptoms with $C h$. amaranticolor. Third type no reaction with hosts, Ch. album, and Ch. qinua (table,3\& fig. 1). , Viccia faba L. (Giza 2) ucumis sativus cv BaetaAlpha and Squash C.pepo $c v$ skandrani. which confirmed by DAS-ELISA

\section{Mode of transmission}

Mechanical transmission: The isolated PVX was mechanically transmitted by finger print and syringe injection to the different hosts. This results were confirmed DAS-ELISA which gave positive results using specific polyclonal antibodies.

Tuber seed transmission. The results showed that isolated PVX was easily transmitted by tuber seeds of cvs. Spunta by $100 \%$. This result was confirmed by positive DAS-ELISA on the resulted infected plants.

Morphology of virus: Rod viral particles with a clear model length of (475) $\mathrm{nm}$ and (12) nm wide were detected in partial purified preparation obtained from infected. N. tabaccum var.sammson leaves as in (fig.3). 
Table 3.Reaction of some different hosts inoculated with PVX isolate.

\begin{tabular}{|c|c|c|c|}
\hline Family & Host & Symptoms & ELISA (OD at $405 \mathrm{~nm})$ \\
\hline \multirow[t]{10}{*}{ Solanicaeae } & Datora metel L & NS & 0.352 \\
\hline & D. stramonium L. & $\mathrm{C}, \mathrm{SM}, \mathrm{LD}$ & 0.072 \\
\hline & Nicotiana glutinosa $L$. & $\mathrm{mM}, \mathrm{VC}$ & 0.334 \\
\hline & N.rustica L. & $\mathrm{VN}, \mathrm{mM}$ & 0.243 \\
\hline & N. samson $L$ & $\mathrm{mM}, \mathrm{Vb}$ & 0.273 \\
\hline & $\begin{array}{l}\text { Pepper, Capsicum annum.cv. } \\
\text { California wonder }\end{array}$ & $\mathrm{mM}, \mathrm{Vb}, \mathrm{C}$ & 0.213 \\
\hline & Petunia hyprida & $\mathrm{mM}$ & 0.185 \\
\hline & $\begin{array}{l}\text { Potato, S.tuberosum.cv. } \\
\text { Spunta }\end{array}$ & $\mathrm{M}, \mathrm{C}, \mathrm{VC}, \mathrm{N}$ & 0.294 \\
\hline & Solanum nigrum $L$. & $\mathrm{M}, \mathrm{Vb}$ & 0.183 \\
\hline & $\begin{array}{l}\text { S. esculantum L. cv. } \\
\text { Castle rock }\end{array}$ & $\mathrm{M}, \mathrm{VC}, \mathrm{LD}$ & 0.276 \\
\hline \multirow[t]{2}{*}{ Fabiaceae } & $\begin{array}{l}\text { Viccia faba } L . \\
\text { Giza } 2\end{array}$ & NS & 0.058 \\
\hline & $\begin{array}{l}\text { Phasolus. vulgaris L. } \\
\text { Giza } 3\end{array}$ & $\mathrm{Vb}, \mathrm{mM}$ & 0.226 \\
\hline \multirow[t]{4}{*}{ Chenopodiacaea } & Beta vulgaris $L$ & $\mathrm{VC}, \mathrm{mM}$ & 0.266 \\
\hline & Chenopodium album & NS & \\
\hline & Ch. Amaranticolor & Ch L L & 0.225 \\
\hline & Ch. quinua & NS & 0.071 \\
\hline \multirow[t]{2}{*}{ Cucrubiacaeae } & $\begin{array}{l}\text { Cucumis sativus } c v \\
\text { Baeta-Alpha }\end{array}$ & NS & 0.065 \\
\hline & $\begin{array}{l}\text { Squash C.pepo } c v \\
\text { skandrani }\end{array}$ & NS & 0.065 \\
\hline
\end{tabular}

Three replicates for each plant species

$\mathrm{NS}=$ no symptoms, $\mathrm{ChLL}=$ chlrotic local lesions, $\mathrm{Vb}=$ vein banding $. \mathrm{VC}=$ vein clearing, $\mathrm{VN}=$ vein necrosis , $\mathrm{M}=$ mosaic, $\mathrm{mM}=$ mild mosaic, $\mathrm{C}=$ crinkling, $\mathrm{LD}=$ leaf deformation, $\mathrm{LCS}=$ leaf cup shape, $\mathrm{N}=$ necrosis, $\mathrm{VN}=$ vein necrosis

Optical density at $405 \mathrm{~nm}$ Negative control $=0.085$, Positive control $=0.382$ 


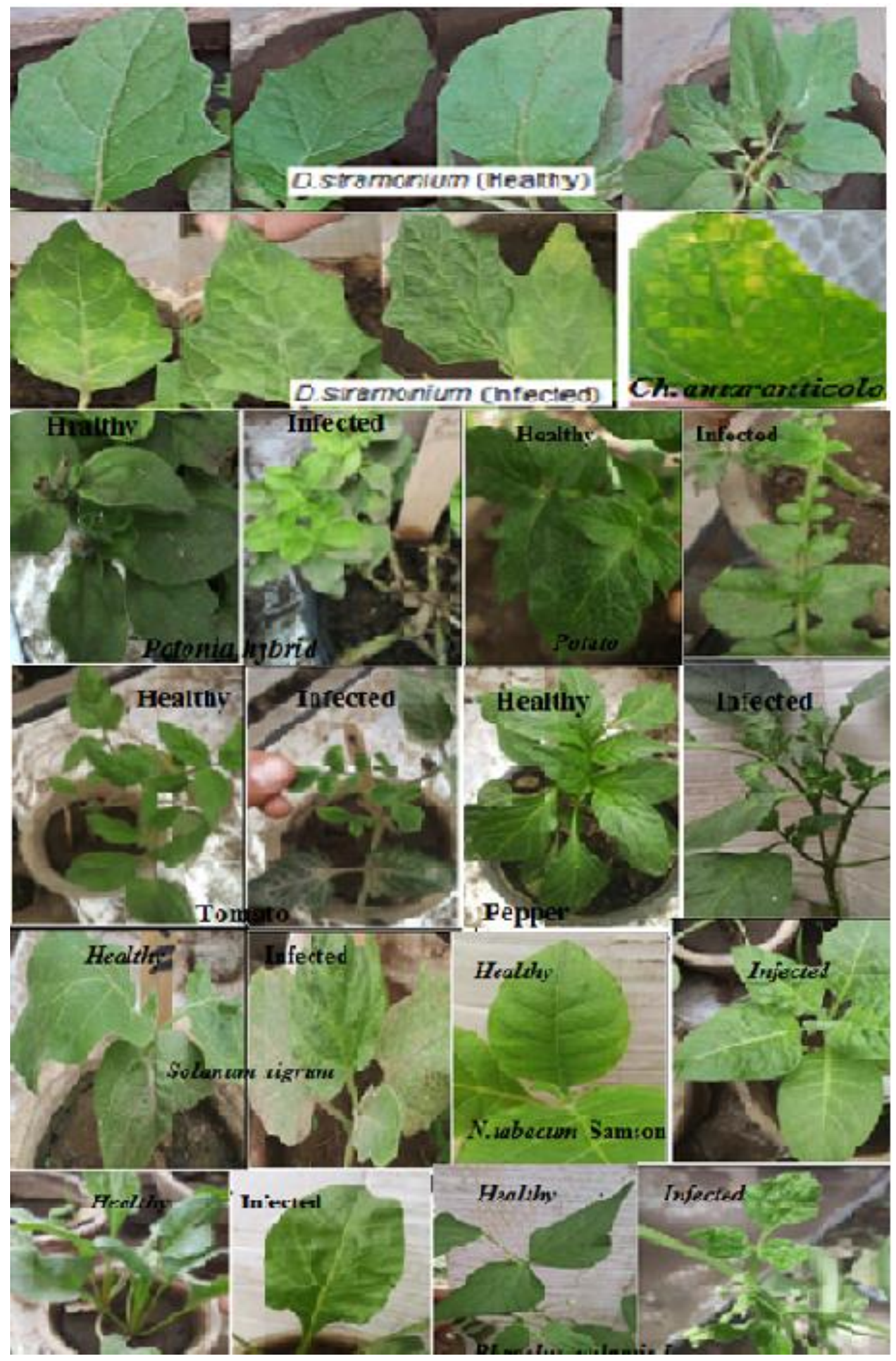

Fig. (2): Reaction of some hosts range inoculated with PVX isolate. 


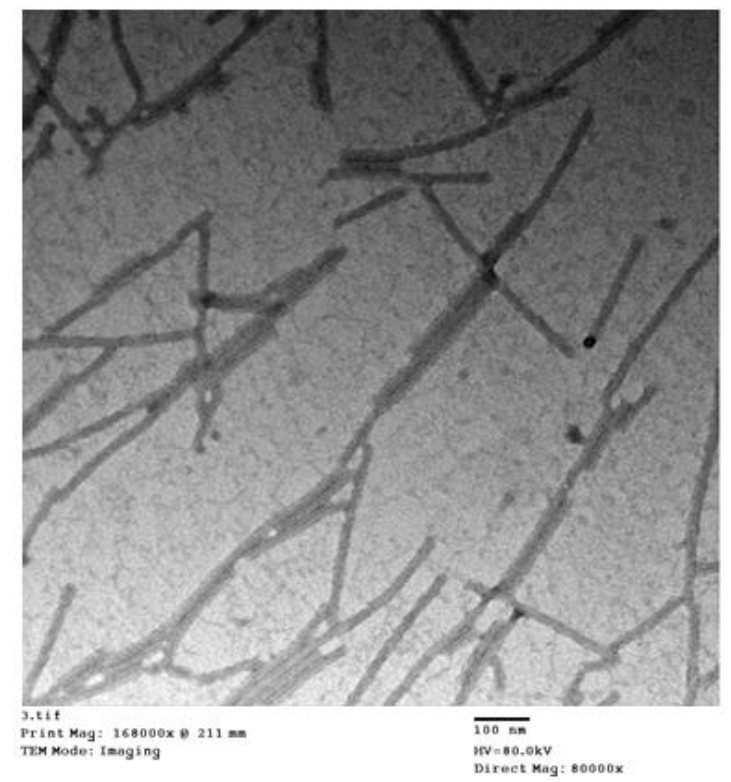

Fig. (3): Photograph showing the rod particles of PVX Isolation using negative stain by TEM at $80000 \mathrm{X}$

\section{Virus stability}

The isolated PVX have the thermal inactivation point (TIP) was expected $85^{\circ} \mathrm{C}$ for 10 min. exposure. with $0 \%$ virus infectivity (table, 4 ).

Table 4. Determination of Thermal Inactivation Point at 10 min. exposure for isolated potato virus based on local lesion assay

\begin{tabular}{llll}
\hline Temperature & $\begin{array}{l}\text { No of } \\
\text { local lesion }\end{array}$ & $\begin{array}{l}\text { \%Virus } \\
\text { infectivity }\end{array}$ & $\begin{array}{l}\text { \%Virus } \\
\text { inhibition }\end{array}$ \\
\hline I.C.S. & 71 & 100 & 100 \\
$50^{\circ} \mathrm{C}$ & 52 & 73.2 & 26.8 \\
$55^{\circ} \mathrm{C}$ & 48 & 67.6 & 32.3 \\
$60^{\circ} \mathrm{C}$ & 40 & 56.3 & 43.7 \\
$65^{\circ} \mathrm{C}$ & 32 & 45.1 & 54.9 \\
$70^{\circ} \mathrm{C}$ & 27 & 38.0 & 62.0 \\
$75^{\circ} \mathrm{C}$ & 15 & 21.1 & 78.9 \\
$80^{\circ} \mathrm{C}$ & 5 & 7.0 & 93.0 \\
$85^{\circ} \mathrm{C}$ & 0 & 00 & 100 \\
$90^{\circ} \mathrm{C}$ & 0 & 00 & 100 \\
\hline
\end{tabular}

Results were calculated from three replicates.

The Dilution End Point (DEP) was expected $10^{-8}$ with $12.0 \%$ virus infectivity (table, 5).

Table 5. Determination of Dilution End Point for isolated potato virus based on local lesion assay .

\begin{tabular}{lllc}
\hline Dilutions & $\begin{array}{l}\text { No of } \\
\text { local lesion }\end{array}$ & $\begin{array}{l}\text { \%Virus } \\
\text { infectivity }\end{array}$ & $\begin{array}{c}\text { \%Virus } \\
\text { inhibition }\end{array}$ \\
\hline Undiluted* $_{10} 1$ & 75 & 100 & 100 \\
$10^{-2}$ & 55 & 73.3 & 26.7 \\
$10^{-3}$ & 43 & 57.3 & 42.7 \\
$10^{-4}$ & 39 & 52.0 & 48.0 \\
$10^{-5}$ & 29 & 39.6 & 60.4 \\
$10^{-6}$ & 20 & 26.6 & 73.4 \\
$10^{-}-$ & 15 & 20.0 & 80.0 \\
$10^{-} 8$ & 10 & 13.3 & 86.7 \\
$10^{-9}$ & 9 & 12.0 & 88.0 \\
\hline
\end{tabular}


Results were calculated from three replicates.

The Longevity (LIV) was $\left(25-28{ }^{\circ} \mathrm{C}\right)$ for 7 days with $12.0 \%$ virus infectivity at room temperature (table, 6$)$.

Table 6. Determination of Longevity of isolated potato virus In Vitro at room temperature based on local lesion assay

\begin{tabular}{llll}
\hline Days & $\begin{array}{l}\text { No of } \\
\text { local lesion }\end{array}$ & $\begin{array}{l}\text { \%Virus } \\
\text { infectivity }\end{array}$ & $\begin{array}{c}\text { \%Virus } \\
\text { inhibition }\end{array}$ \\
\hline Zero time. & 62 & 100 & 100 \\
1 days & 52 & 83.9 & 16.1 \\
2 days & 48 & 77.4 & 22.6 \\
3 days & 36 & 58.1 & 41.9 \\
4 days & 23 & 37.1 & 62.9 \\
5 days & 17 & 27.4 & 72.6 \\
6 days & 10 & 16.1 & 83.9 \\
7 days & 8 & 12.9 & 87.1 \\
8 days & 0 & 100 & 0 \\
10 days & 0 & 100 & 0 \\
\hline
\end{tabular}

Results were calculated from three replicates.

Inclusion bodies : Amorphous and crystal inclusion bodies were induced by PVXisolate were detected in cells of epidermal strips. As well as showed open stomata in healthy leave and closed stomata in infected N.tobaccum cv. Samson leaves (fig.3) .

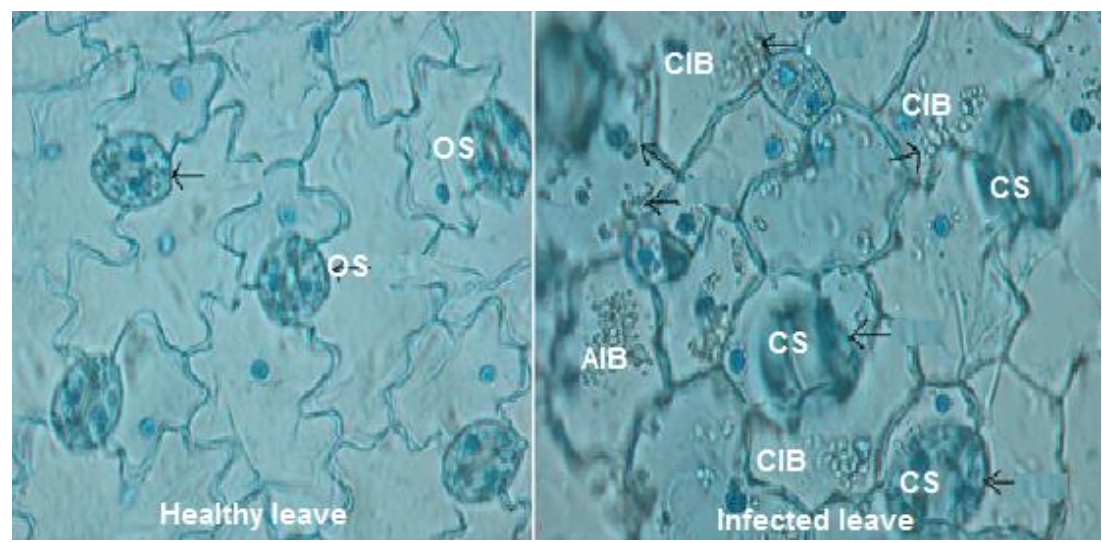

Fig.3: Photoplate showing epidermal cells of N.tabacum CV samson leaves of healthy and infected with PVX isolate showing, closed Stomata (CS), opened Stomata (OS), amorphous inclusion bodies (AIB) and crystalline inclusion bodies (CIB) .

Serological characters: The infectious sap of isolated PVX was reacted by serologically precipitation with specific polyclonal antibodies of PVX particles using DAS ELISA. The serological precipitation reaction was proved the particles of isolated PVX have antigenicity .
Virus infectivity : The obtained results revealed that PVX infected potato plants with $90 \%$ PVX infectivity and $85 \%$ disease severity . On the other hand, it was observed high concentration of PVX inoculated potato plants (table,7).

Table 7. Disease severity and Virus concentration of PVX infected potato plant.

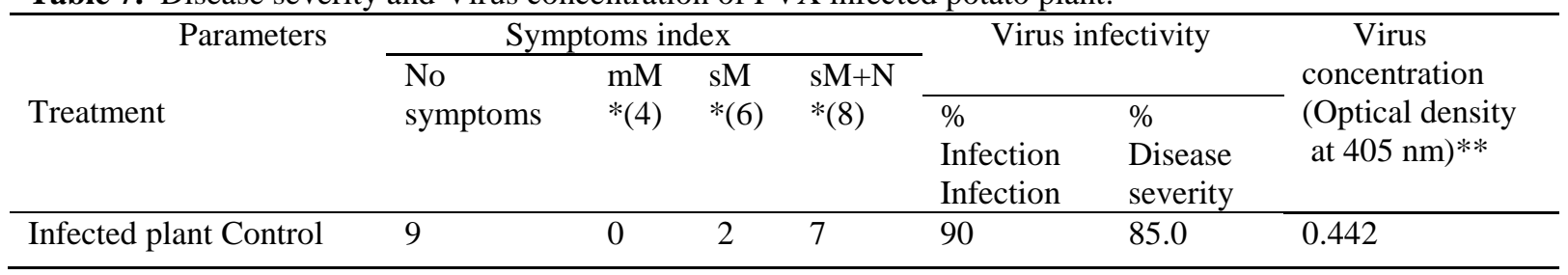

Total inoculated plants $=80$ plants .

* Degree of Symptoms index ( $4 \mathrm{mM}=$ mild mosaic ), (6 $\mathbf{s M}=$ sever mosaic) , ( $\mathrm{N}=$ necrosis)

**Virus concentration was determined at the means of three replicates by DAS ELISA .

OD 405 nm, Negative $=0.1245$, Positive $=0.475$ 


\section{Molecular characters of PVX}

Total RNA extraction : The integrity and quantity of the total purified RNA were confirmed by gel electrophoresis and UV spectrophotometer. The concentration of PVX-EG/RNA was $80 \mu \mathrm{g} / 0.5 \mathrm{gm}$ of infected tissues and the purity of the total RNAs obtained measured by an A260/280 absorbance ratio (1.6) for PVX indicating high yield and purity of the extracted RNAs.

cDNA of PVX-EG-RNA : The total RNAs prepared from infected plants were reverse transcribed using PVX sense primer (5'GATGTTGCA GAAGCGTATAT3').

Amplification of cDNA-PVY-EG:- The PVX DNA was amplified from RNAs extracted from infected $N$. tabaccum cv.samson leaves using PCRtechnique. The resulting complementary DNA $(1 \mu \mathrm{l}$ of cDNA) was mixed with $\mathrm{PCR}$ reaction mixture, taq DNA polymerase and (sense and antisense) primers directly.

Electrophoresis analysis of RT-PCR-product: RT-PCR was used to amplify a fragment of about 588 bp corresponding to the C-terminal region of $\mathrm{CP}$ gene. The size of the PCR product amplified from PVX- was estimated by comparing its electrophoretic mobility with those of standard DNA marker as shown in (Fig. 4). The efficiency of cDNA amplification from PVX infected leaf tissues using sense and antisense primers by analysis PCR product using $1.5 \%$ agarose gel electrophoresis. The amplified cDNA was in the expected size calculated (450 bp) from the positions of sense and antisense primers.

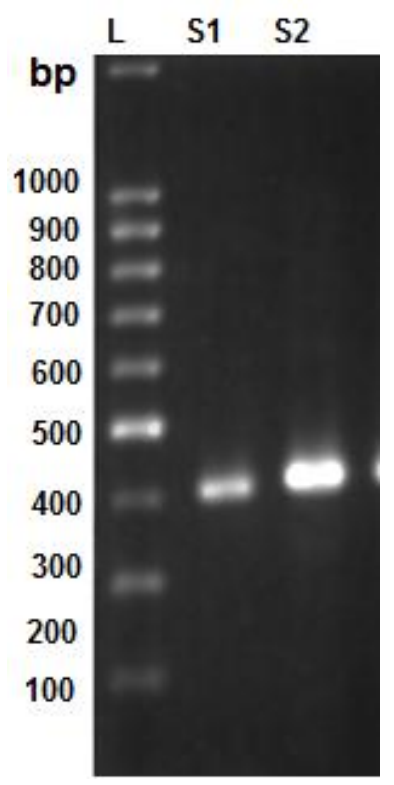

Fig. (4): Electrograph of Agarose gel electrophoresis showing (A) RT-PCR product amplified PVX- CP portion from total RNA extracted from infected potato leaves using primers . (B) PVY RT-PCR product (after purification). L: DNA ladder weight marker (100 bp ladder) .

Nucleotide sequence analysis:- The partial nucleotide sequence of the PCR-amplified fragment found to be $433 \mathrm{bp}$ corresponding the C-terminal region of CP gene of PVX isolate. The relationship with other recommended PVX strains registered in GenBank. was done from the forward direction at Macrogen3730XL6-1518-009, Korea (Fig.5).

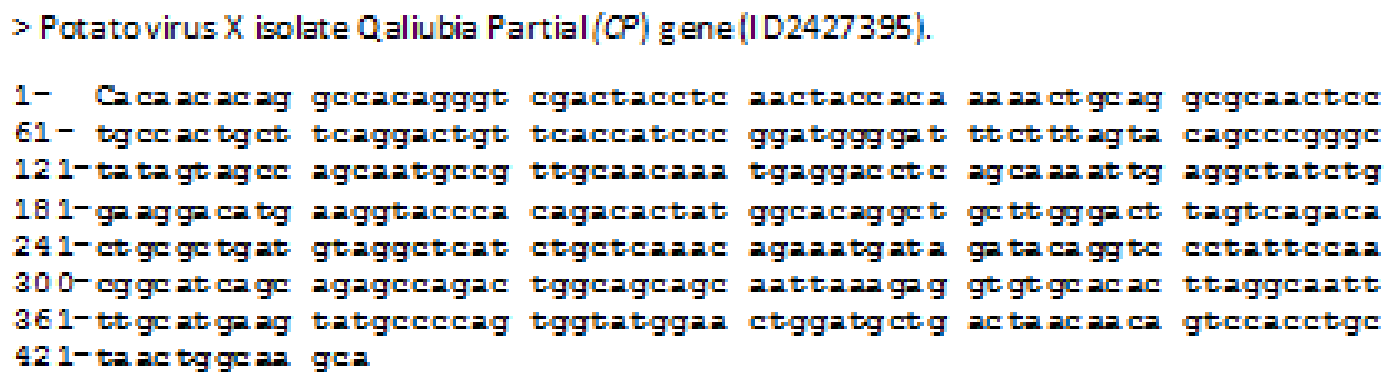

Fig.(5): The nucleotide sequence of partial CP gene (435 bp highlighted) of PVX-EG-strain (ID2427395).. 
Viroinformatic analysis of molecular data: The partial nucleotide sequence of CP gene of PVX isolate was aligned with twenty two isolates of PVX recorded in gene bank (fig.6) . All of these sequences were multiple-aligned with the clustal $\mathrm{W}$ program with minor manual adjustments, resulting 433 bp positions including the gaps (Fig. 6).

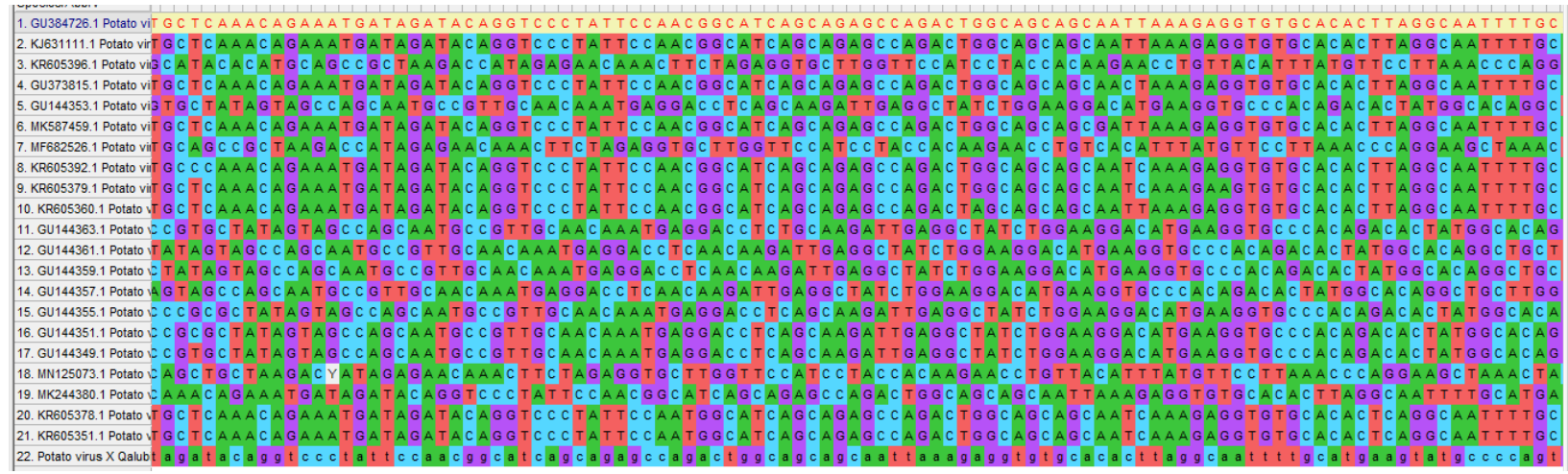

Fig.(6).The multi alignments partial nucleotide sequence of CP gene of PVX isolate (MW650651) was aligned with twenty two PVX isolates recorded in gene bank

The Neighbour-joining tree of coat protein gene of PVX with 22 PVX isolates published in GenBank was bar 10 the nucleotide distances (fig.7 ). The lower values were recorded for isolate pairs PVX with Accession no.MK587495, MF662526,
KR605392, KR605379 , KR605360 with $97.92 \%$ similarity . The higher nucleotide distance values were recorded for isolate pairs Accession no.KJ631111 with $98.30 \%$ similarity (table,8).

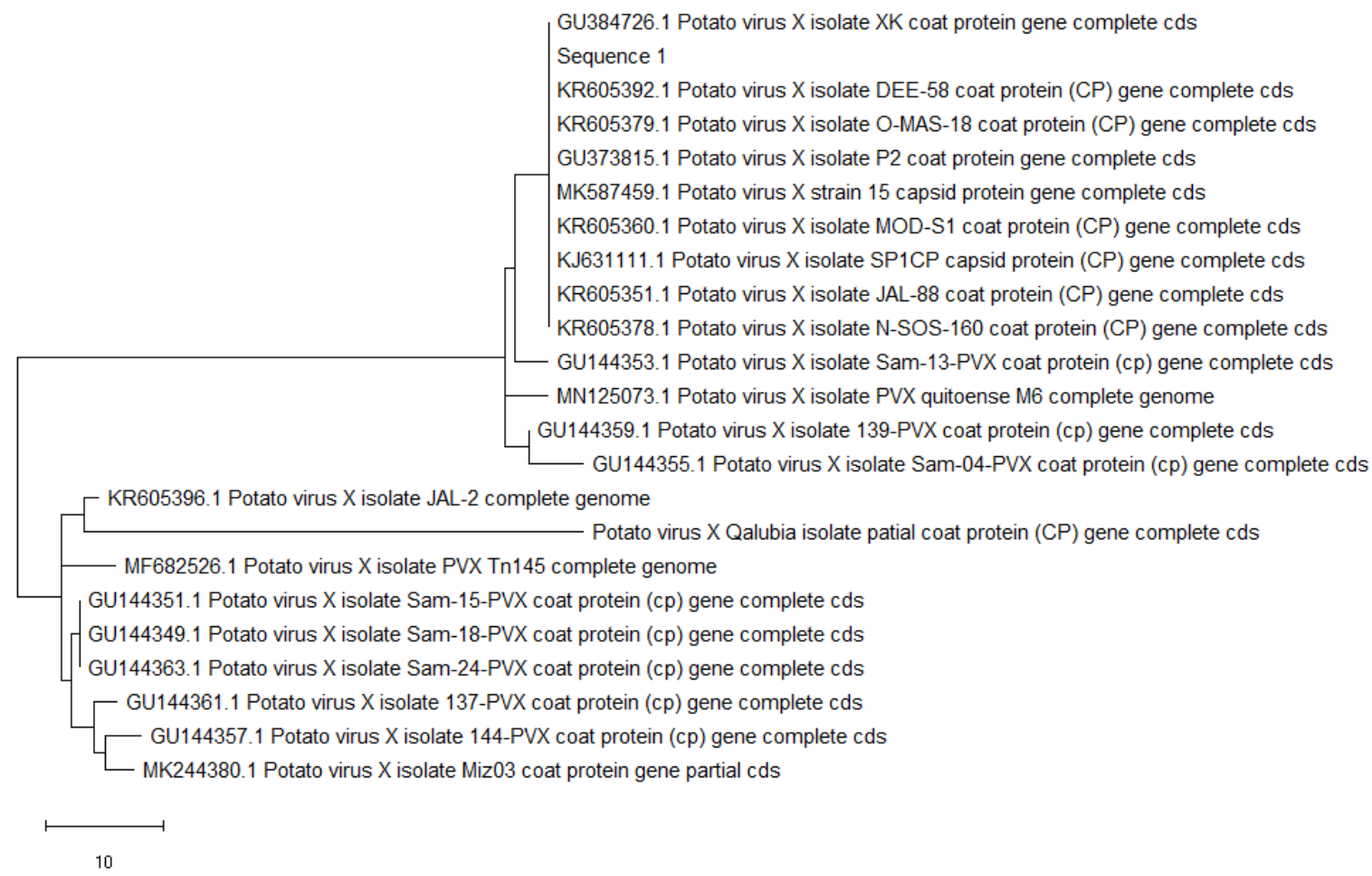

Fig. (7). Neighbour-joining tree of coat protein gene of PVX and 22 PVX isolates published in GenBank. Numbers represent bootstrap percentage values based on 1000 replicates 
Table (8): Nucleotide distances and standard error between coat protein gene of PVX isolate and 10 PVX isolates published in GenBank

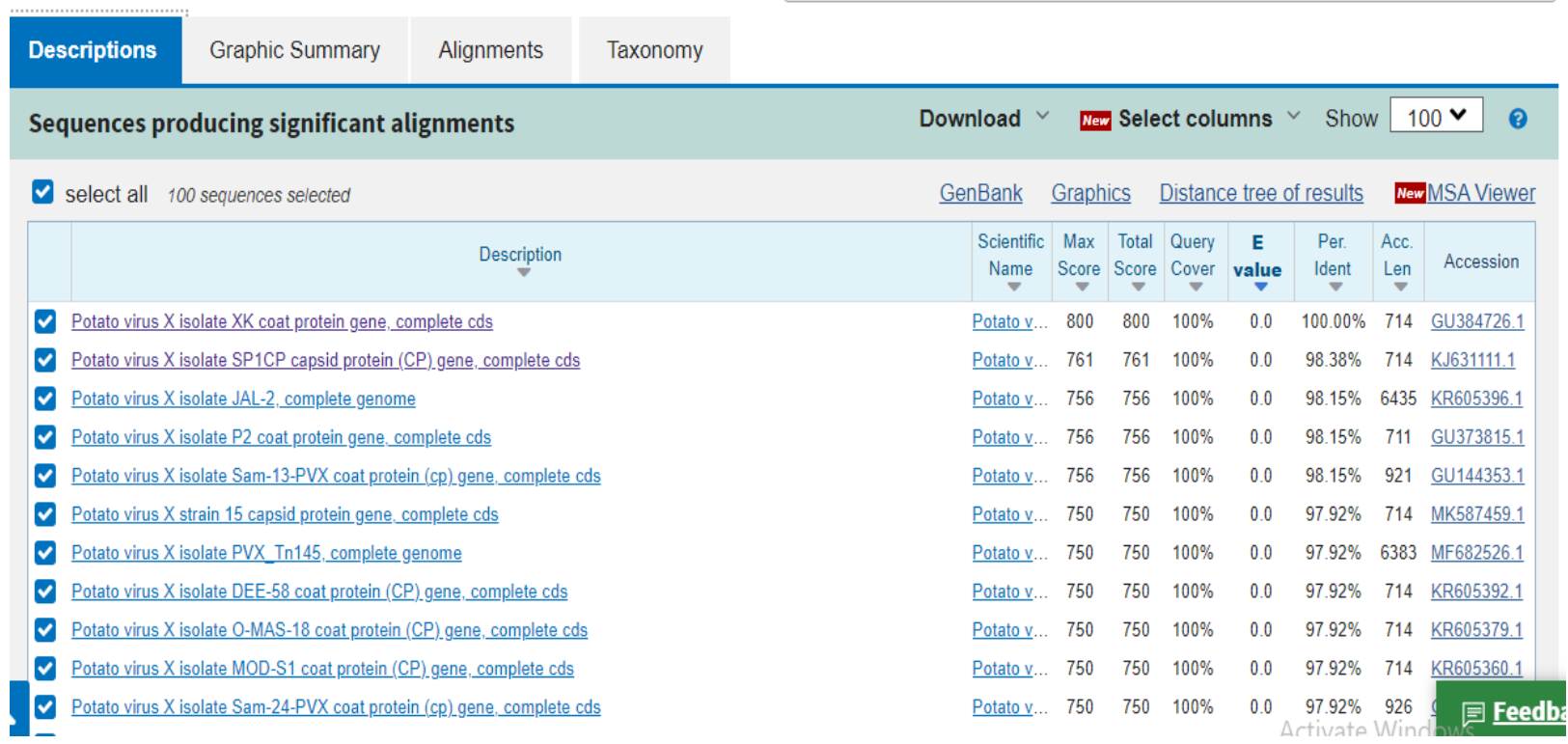

Translation of PVY-EG strain partial CP gene nucleotide sequence : The predict numbers of amino acids were produced from translation of partial (CP) gene nucleotide sequence were 144 amino acids starting with methionine (Fig. 8)

\section{1- TTQATGSTTS TTTKTAGATP ATASGLFTIP DGDFFSTARA IVASNAVATN EDLSKIEAIW 61- KDMKVPTDTM AQAAWDLVRH CADVGSSAQT EMIDTGPYSN GISRARLAAA IKEVCTLRQF 121-CMKYAPVWWN WMLTNNSPPA NWQA}

Fig. (8): Translation of partial nucleotide sequence of CP gene for an Egyptian PVX-isolate produced 144 amino acids .

The partial CP gene amino acid sequence for PVXEG was aligned with 21 isolates of PVX (fig 9). All these sequences were multiple-aligned with the clustalw program with minor manual adjustments . resulting in 104 positions including the gaps (Fig. 9).

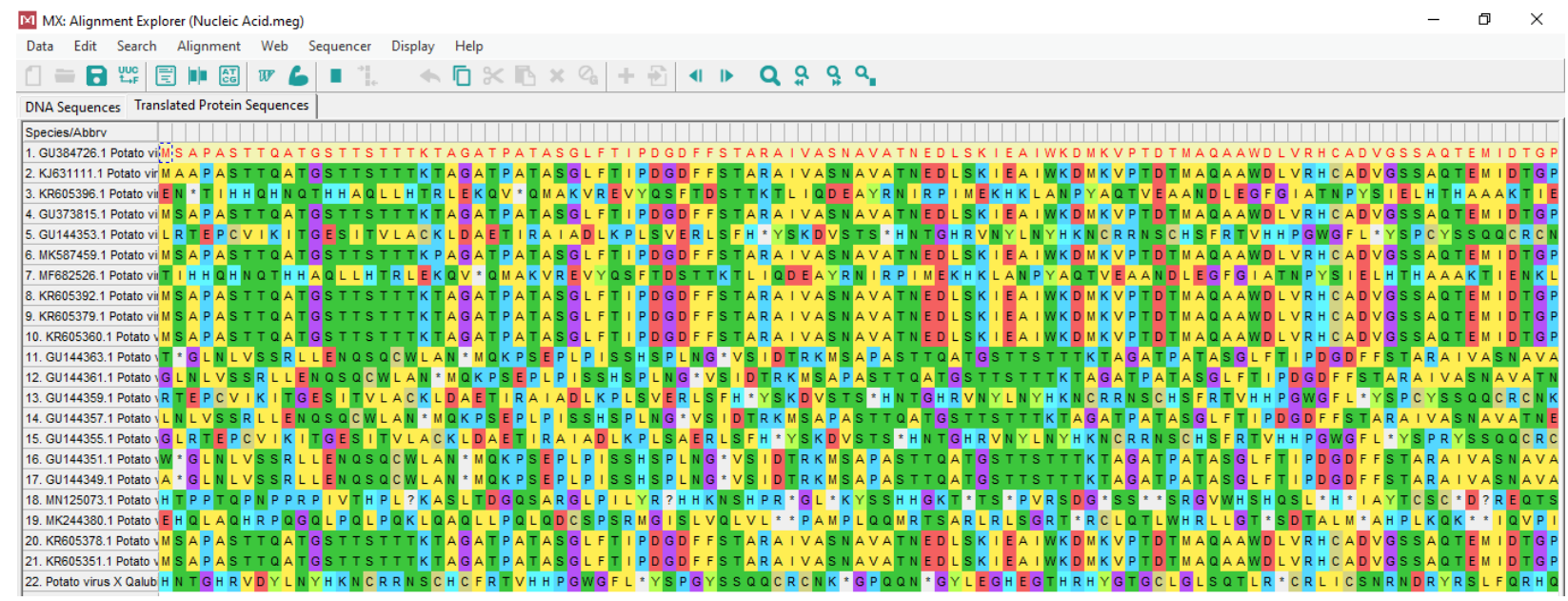

(Fig.9): Multiple alignment amino acid sequence of the partial CP gene of PVX / CP-EG isolate with the corresponding amino acid sequence of 21 PVX isolates available in GenBank 
The distances between isolates ranged bar 0.20 (fig.10 ). The lower values were recorded for isolate pairs PVX with Accession no. GU144349 . The higher values were recorded for isolate pairs PVX with Accession no. GU144353 .

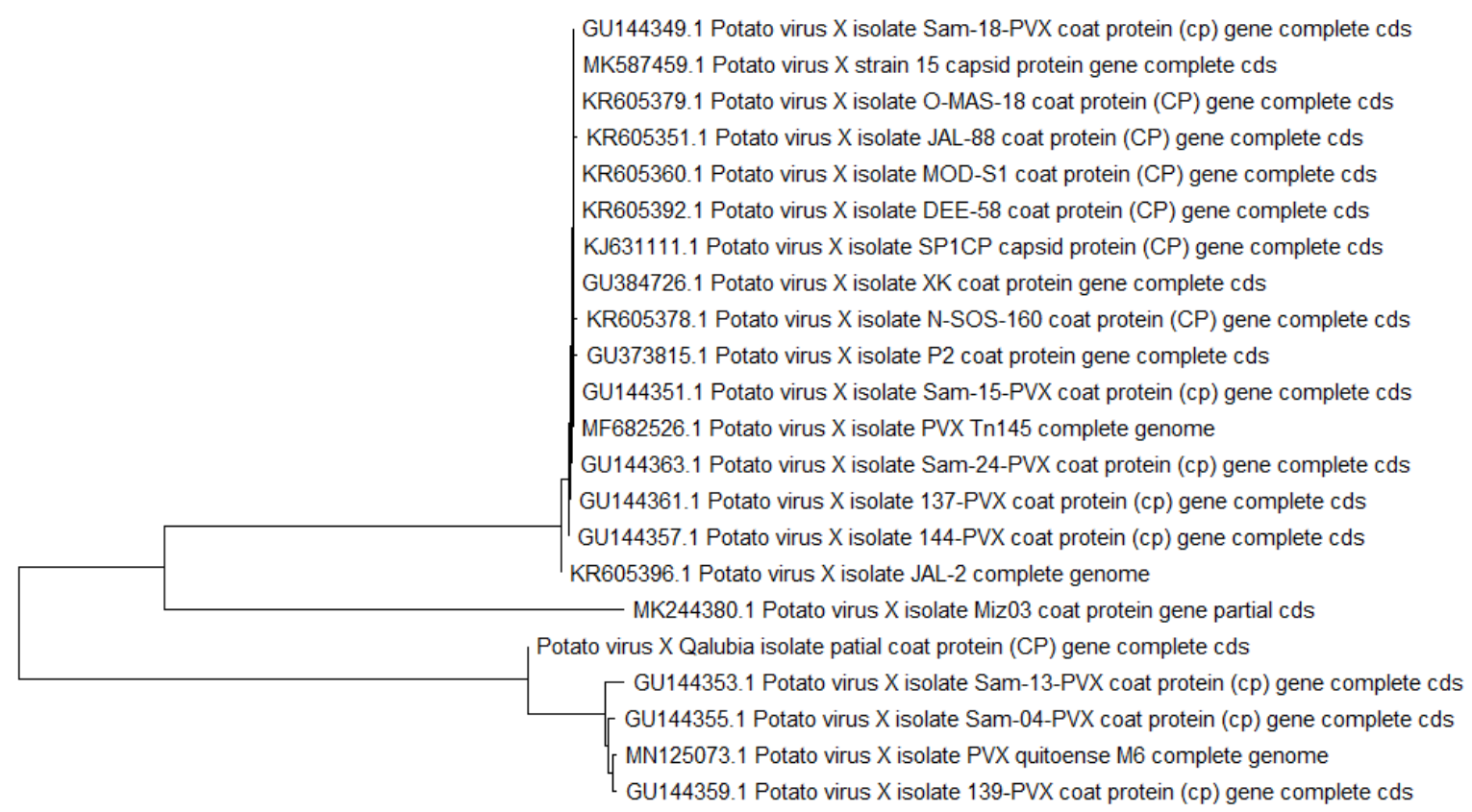

0.20

(Fig. 10): Neighbour joining tree of PVX and 22 PVX isolates published in GenBank based on the amino acid sequence of the $\mathrm{CP}$ gene. Numbers represent bootstrap percentage values based on 1000 replicates

\section{Discussion}

In naturally the most common viruses affecting potato crops throughout the world are Potato virus $Y$ (PVY, potyviruses), Potato virus $X$ (PVX, potexvirus) and Potato leaf roll virus (PLRV, luteovirus). Egypt imports all potato seeds for planting from Europe, where theses viruses are present. The current method routinely used for detection of these viruses is ELISA(Clark andAdam1977). and there are no procedures to detect these three viruses in one step reaction. Multiplex-RT-PCR for PVY strains has been reported by Nei and Singh (2002) and Shalaby,et al., (2016) - This finding was confirmed by Du $\boldsymbol{e t}$ al. (2006) mentioned that a multiplex RT-PCR protocol for simultaneous detection of five potato viruses as an internal control. The protocol simultaneously amplified cDNAs from PVA, PVX, PVY, PLRV, PVS, and 18S rRNA. The m-RT-PCR protocol was able to detect all viruses in different combinations. The technique was 100 -fold greater for detection of PVX than that of commercial DAS ELISA, and also could detect viruses in some samples that DAS-ELISA failed to detect. This multiplex RT-PCR technique demonstrates a higher sensitivity of virus detection than DASELISA.) (Ghanim,et al,.1998) . Potato virus $\mathrm{X}$ is spread in Egypt and all over the world and infects potato cultivar plants (Hegazy, 2009; Mahfouze et al., 2014 and Ohbayashi, 2019). Potato (Solanum tuberosum L.) often becomes infected with two to three different viruses. The reaction of potato cV spunta with PVX isolate showed differed type of systemic symptoms showed vein clearing, severe mosaic, crinkling, disease severity $85.0 \%$ and virus concentration 0.442 OD. . According to the DASELISA results, the rate of the virus concentration in potato c.v spunta have been increased susceptible to the virus infection. Fayziev, et al., 2020) reported that virus concentration was similar between D. stramonium leaf samples infected with PVXO-Uz 214 isolate and PVXN-Uz 915 isolate .

According to the reaction of potato cV Spunta with PVX isolate showed different susceptibility based on symptoms and ELISA test. (Crissman $\boldsymbol{e t}$ al., 1991, Isenegger et al., 2001 and El-Dougdoug et al., 2014).

In general, the responses of plants to pathogen infections are characterized by metabolic changes associated to the development of the symptoms or to defense reactions.

PVX isolate which was previously isolated and identified from systemically infected potato plants. The isolate of PVX were biologically confirmed on 
differential hosts and serological by DAS-ELISA. The PVX isolate gave local lesions on $C h$. amaranticolor L., (Allam et al., 1973 Querci et al., 1995 and sherin, 2003). and vein banding on $D$. stramonium L, mild mosaic on $N$. glutinosa L. and $N$. tabacum cv. White Burley (Allam et al., 1973 and Fribourg, 1975) mild mosaic on Lycopersicon esculentum cv. Super Marmande.

Also, it was gave positive reaction with specific PVX IgG polyclonal antibodies by DAS-ELISA (Singh and Somerville 1983). PVX was propagated on $D$. stramonium L respectively (Andra et al 1998 and Fribourg 1975).

The virus was spread more easily direct contact of healthy with infected plants is a well-known means of spreading PVX.by this means in potato, and virulent strains spread more easily than avirulent strains. PVX also is transmitted from infected to healthy sprout tubers stored in the same bag. . Various grafting techniques are used to transmit PVX (DAN and Jone 1981)

RT-PCR amplification of viral RNA was carried out on the total RNA from infected plants using specific primers designed to amplify the coat protein gene. Electrophoresis analysis of RT-PCR product showed a single amplified fragment of $433 \mathrm{bp}$ and no fragments were amplified from the RNA . Soliman,et al ., (2006) found that, RT-PCR amplification of PVX using specific primers designed to amplify the coat protein gene $750 \mathrm{bp}$ and no fragments were amplified from the RNA . Nucleotide sequencing of the RT-PCR amplified fragment in the PVX-CP was completed to determine if this PCR fragment was from potexvirus group or not and to compare the sequence from this isolate with those of other potato-infecting potexvirus group available in GenBank . (Soliman,et al ., 2006). The nucleotide sequence of the coat protein gene of the Egyptian isolate of PVX was submitted in the GenBank under Accession No. AY763582. The CP gene codes for a 144 amino acid protein starting methionine. Soliman,et al ., (2006) found that The predicted PVX-CP gene is $714 \mathrm{nt}$ in size, starting from ATG start codon (methionine), as obtained by comparison with other PVX sequences, and ending with a TAA stop codon from which the 3 ' NCR (non coding region) ends. The $\mathrm{CP}$ gene codes for a 238 amino acid protein giving a molecular weight of 25 $\mathrm{KDa}$ (kilo Dalton). , as obtained by comparison with other PVX sequences. Multiple sequence alignment of the nucleotide sequence of the coat protein gene of PVX [Egyptian isolate (AY763582)] with the corresponding sequence of seven different PVX isolates available in GenBank [Netherlands (X72214); UK (Z23256); Spain (AJ505748); Italy (AX342361); Canada (AF202462); Japan (AB056718); and China (AF594312)] were analyzed using DNAMAN software. Sequence comparisons showed the percentage of similarity ranged from 80 $96 \%$ of the seven reported isolates of PVX with the
Egyptian isolate. The results indicated that the highest sequence similarity was found between PVX$\mathrm{Eg} 2$ isolate and PVX isolates from Spain, China, Canada, Italy, and Japan at 96\%, while the lowest was found with PVX isolates from Netherlands and UK at $80 \%$

The interaction between the antigen and the specific antibody is the basis for serological tests. Polyclonal antibody raised against the PVX was able successfully to detect PVX isolate at dilution of 1 : $1000(\mathrm{v} / \mathrm{v})$. ELISA has been widely used for the detection of viral diseases in many plants (Salazar, 1996).

\section{References}

Allam, E.K.; Abd El-Nasr; M., Othman B.A.and thabet , S.D. (1994). A new method for mechanical transmission of tomato yellow leaf curl virus. Egyptian Phytopath. Society, $7^{\text {th }}$ congress of phytopathology Cairo, pp 77-91.

Allam, E.K.; R.A. Omar and A.A. El-Amrety (1973). Compartive studies on three strains of PVX isolated from naturally infected potato in Egypt 1.host range, physical properties and transmission. J. Phytopathol. 5: 19-30.

András Takács ; Kazinczi G.; Horváth J. and Pribék D. (1998). Reaction of wild Solanum species to the tuber necrosis strain of potato $\mathrm{Y}$ potyvirus (PVYNTN). Novenytermeles 47(1):14.

Bercks, R. (1970). Potato virus X. CMI/AAB Description of Plant Viruses. No. 4, 4 pp.

Clark, M. F., and Adams, A. (1977). Characteristics of the microplate method of enzyme-linked immunosorbent assay for the detection of plant viruses. Journal of General Virology, 34(3), 475-483.

Crissman, C. C., El Bedewy, R., Sabaa, M. F., and Sharaf, M. F. (1991). Agroeconomic evaluation of different types of potato planting material in Egypt: CIP Lima.

Dan E.P. and R.E. Jone (1981): Potexviruses .In: Handbook of plant virus infections and comparative diagnosis-E. Kurtstak (ed.)Elsevier North-holland Biomedical. Press (642-651).

Du, Z.; J. Chen and C. Hiruki (2006). Optimization and Application of a Multiplex RT-PCR System for Simultaneous Detection of Five Potato Viruses Using 18S rRNA as an Internal Control. 90(2): 185-189.

El-Dougdoug, K. A; Sofy, A.R; Mousa, A.A. and Refaey, E.E. (2014). Monitoring variability responses of cultivated potato varieties infected with Potato virus Y pepper isolate. Egyptian J. Virol., 11 (2): 82-101.

Faostat, (2018). (http://apps.fao.org).

Fayziev V, Vakhabov A (2019) .The study of the biological properties of potato virus $\mathrm{X}$ in 
common environmental conditions of Uzbekistan// European Sciences review. № 1-2 Volume 2, p. 46-50.

Fayziev 1,V., Jovlieva D , Juraeva ,U., Shavkiev, I, Farkhod Eshboev F.,and Stat, F. FAO. (2020). Effect of PVX -UZ 915 necrotic isolate of potato virus $\mathrm{X}$ on amount of pigments of Datora stramonium leaves Journal of criteria review 7 , issue $9,400-417$.

Fribourg, C.E. (1975). Studies on potato virus X strains isolated from Peruvian potatoes. Potato Res. 18: 216-226.

Ghanim, M., Morin, S., Zeidan, M. and Czosnek, H. Evidence (1998). for Transovarial Transmission of Tomato Yellow Leaf Curl Virus by Its Vector, the Whitefly Bemisia tabaci. Virology 240, 295-303.

Hefferon, K. L., Khalilian, H., Xu, H., and AbouHaidar, M. G. (1997). Expression of the coat protein of potato virus $\mathrm{X}$ from a dicistronic mRNA in transgenic potato plants. J. Gen. Virol., 78, 3051-3059.

Hegazy, E. S. (2009). Seed potato production in Egypt. Agro-Food Co. Ltd., Egypt.

Huisman, M. J., Linthorst, H. J. M., Bol, J. F., and Cornelissen, B. J. C. (1988). The complete nucleotide sequence of potato virus $\mathrm{X}$ and its homologies at the amino acid level with various plus-stranded RNA viruses. J. Gen. Virol., 69, 1789-1798.

Isenegger, D. A., Taylor, P. W., Ford, R., Franz, P., McGregor, G. R., \& Hutchinson, J.F. (2001). DNA fingerprinting and genetic relationships of potato cultivars (Solanum tuberosum L.) commercially grown in Australia. Crop and Pasture Science, 52(9), 911- 918.

Joojin Jeong, Sang-Yun Cho, Wang-Hyu Lee, Kui-jae Lee, and Ho-Jong Ju (2015). Development of a Rapid Detection Method for Potato virus $\mathrm{X}$ by Reverse Transcription Loop-Mediated Isothermal Amplification. Plant Pathol J. 31(3): 219-225.

Jordan, B.M. and Baker, J.R. (1955): A simple pyronin methyl green technique. Quad. S. Microscope. Sci.; 96:177.

Mahfouze, H., El-Sayed, O., El-Dougdoug K. A, O. B., \& Gomaa, M. (2014). Molecular and biochemical markers for resistance to potato virus $\mathrm{Y}$ and potato virus $\mathrm{X}$ in some potato cultivars.. Scientia Agriculturae, 1, 49-57.

Nie, X., and Singh, R.P.( 2001). A novel usage of random primers for multiplex RT-PCR detection of virus and viroid in aphids, leaves, and tubers. J. Virol. Methods 91:37-49.

Nie, X., and Singh, R.P. (2002). A new approach for the simultaneous differentiation of biological and geographical strains of Potato virus $Y$ by uniplex and multiplex RT-PCR. J. Virol. Methods 104:41-54.
Noha K. El-Dougdoug and Naglaa M.Balabel (2020): Physiological and Molecular Defense Level in Potato Cultivars against Potato Virus X. Annals of Agric. Sci., Moshtohor. Vol. 58(4) ,1079 - 1088.

Noordam, D. (1973). Identification of plant viruses: Methods and experiments. Center for Agriculture Publishing and Documentation, Wageningen, the Netherlands, 207p.

Nyalugwe, E. P., Wilson, C. R., Coutts, B. A., and Jones, R. A. C. (2012). Biological properties of Potato virus $\mathrm{X}$ in potato: Effects of mixed infection with Potato virus $\mathrm{S}$ and resistance phenotypes in cultivars from three continents. Plant Dis. 96:43-54.

Ohbayashi , K. (2019). The Rx gene derived USDA 41956 and Rx1 gene derived CPC 1673 confer equal resistance to the migration of Potato virus $\mathrm{X}$ from potato leaves to tubers . Euphytica 215(5) DOI: $10.1007 / \mathrm{s} 10681-019-2413-6$

Puurand, U., Makinen, K., Paulin, L., and Saarma, M. (1994). The nucleotide sequence of potato virus A genomic RNA and its sequence similarities with other potyviruses. J. Gen. Virol., 75, 457-461.

Querci, M.; D.C. Baulcombe; R.W. Goldbach and L.F. Salazer (1995). Analysis of the resistance breaking determinates of potato virus X (PVX) strain $\mathrm{HB}$ on different potato genotypes expressing extreme resistance to PVX. Phytopathol. 85(9): 1003-1010.

Salazar, L. F. (1996). Potato viruses and their control. Chapter 6. International Potato Center (CIP).

Shalaby A.A., Mazyad , M, and . Soliman ,A,M. (2016). Virus detection: PVY, PVX and PLRV Method: MULTIPLEX - RT-PCR Technical Sheet No. 24 https://www.researchgate.net/publication/242131 674.

Sherin, A. Mahfouze (2003). Diagnosis of some plant viruses using modern techniques. M.Sc Fac. of agric. Ain shams univ.179pp.

Singh, R.P. and T.H. Somerville (1983). Effect of storage temperature on potato virus infectivity levels and serological detection by enzyme linked immunosorbent assay. Plant Disease; 67(10): 1133-1136.

Smith, K. M. (1931). On the composite nature of certain potato virus diseases of the mosaic group as revealed by the use of plant indicators and selective methods of transmission. Roy. Soc. London. Pro. Ser. B., 109, 231-267.

Soliman, A. M., Shalaby, A. A., Barsoum, B. N., Mohamed, G. G., Nakhla, M. K., Mazyad, H. M., and Maxwell, D. P. (2000). Molecular characterization and RT-PCRELISA detection of a potato virus $\mathrm{X}$ (PVX) isolate from Egypt. Annals Agric. Sci., Sp. Issue, 4, 1791-1804. 
Soliman,A.M., Barsoum,B.N., Mohamed,G.G. , El-Attar,A.K. and H. M. Mazyad,H.M.(2006). Expression of the coat protein gene of the Egyptian isolate of potato virus $\mathrm{X}$ in Escherichia coli and production of polyclonal antibodies against it. Arab J. Biotech., Vol. 9, No. (1): 115128.

Thompson, J, D.; Higgins, D. G. and Gibson, T. J. (1997). Clustal W: improving the sensitivity of progressive multiple sequence weighting, position-specific gap penalties and weight matrix choice. Nucleic acid Research.22:4673-4680

Torrance, L., Larkins, A. P., and Butcher, G. W. (1986) . J. Gen. Virol., 67, 57-67.
Walkey, D.G.A. (1985): Applied Plant Virology Wiley-Interscience Publications, New York,USA, PP.93-102

Yang ,X., Liangyi, K. and Tien ,P. (1996): Resistance of tomato infected with cucumber mosaic virus satellite RNA to potato spindle tuber viroid. Ann. Appl. Biol. 129: 543-551.

Yun, S. L., Yau. H. H., and Na, S. L. (2000). Generation of subgenomic RNA directed by a satellite RNA associated with bamboo mosaic potexvirus: analyses of potexvirus subgenomic RNA promoter. J. Virology (22), p. 10341-10348. 


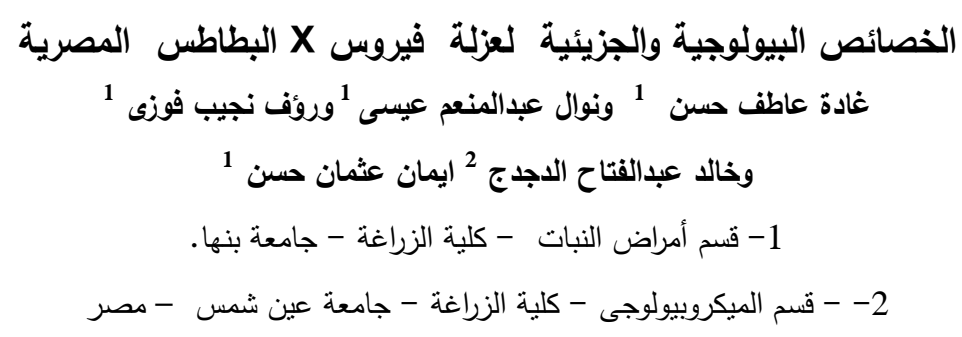

*Corresponding author: eman.ali@fagr.bu.edu.eg

تم التعرف على فيروسات البطاطس في العديد من البلدان حول العالم بما في ذلك مصر • يعد فيروس البطاطس (PVX) أحد الفيروسات الثائعة

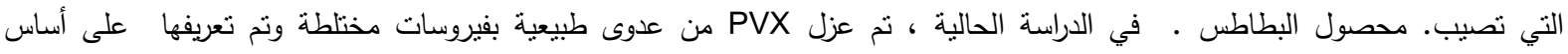

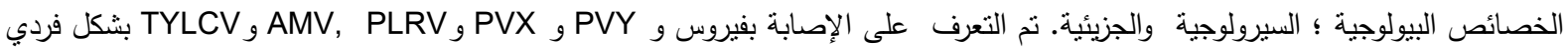

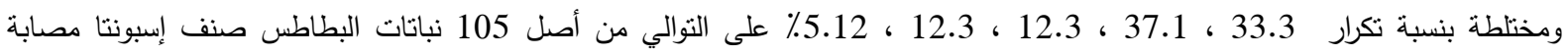

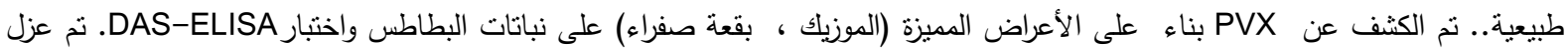

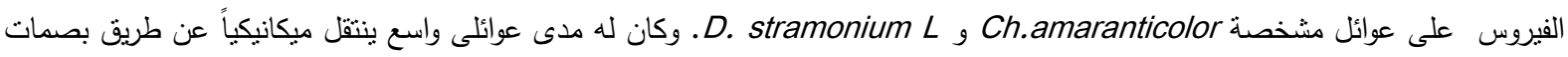

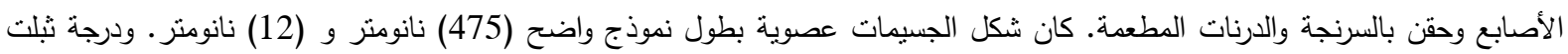
الفيروس

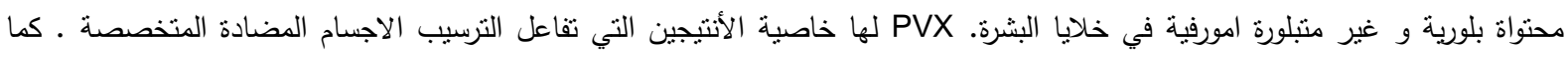

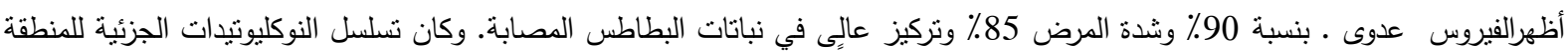

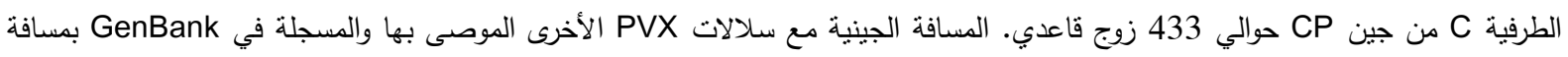

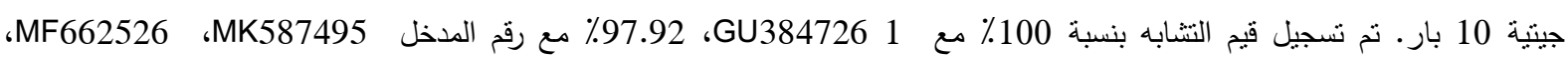

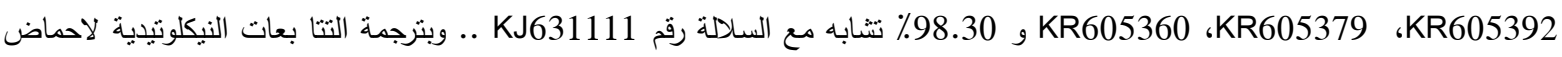
امينية كانت المتوقعة 144 من الأحماض الأمينية تندأ بالثيروزين. المسافة الجينية مع سلالات PVX الأخرى الموصى بها والمسجلة في بات

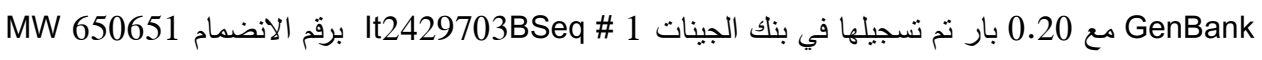
الكلمات الرئيسية: PVX ؛ نطاق المضيفين . RT PCR . TEM . DAS-ELISA ؛ جين الغظاء البروتين بنك الجينات ، 